Article

\title{
Experimental Analysis on the Thermal Management of Lithium-Ion Batteries Based on Phase Change Materials
}

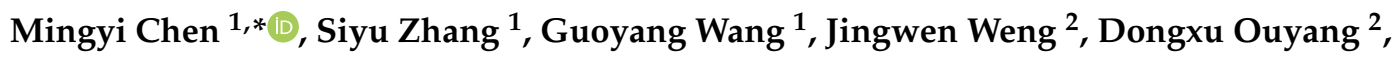 \\ Xiangyang $\mathrm{Wu}^{1}$, Luyao Zhao ${ }^{1}$ and Jian Wang ${ }^{2}$ \\ 1 School of the Environment and Safety Engineering, Jiangsu University, Zhenjiang 212013, China; \\ 2211909027@stmail.ujs.edu.cn (S.Z.); 2211909026@stmail.ujs.edu.cn (G.W.); wuxy@ujs.edu.cn (X.W.); \\ zhaoly@ujs.edu.cn (L.Z.) \\ 2 State Key Laboratory of Fire Science, University of Science and Technology of China, Hefei 230026, China; \\ wengjw@mail.ustc.edu.cn (J.W.); ouyang11@mail.ustc.edu.cn (D.O.); wangj@ustc.edu.cn (J.W.) \\ * Correspondence: chenmy@ujs.edu.cn
}

Received: 10 September 2020; Accepted: 19 October 2020; Published: 21 October 2020

\begin{abstract}
Temperature is an important factor affecting the working efficiency and service life of lithium-ion battery (LIB). This study carried out the experiments on the thermal performances of Sanyo ternary and Sony $\mathrm{LiFePO}_{4}$ batteries under different working conditions including extreme conditions, natural convection cooling and phase change material (PCM) cooling. The results showed that PCM could absorb some heat during the charging and discharging process, effectively reduce the temperature and keep the capacity stable. The average highest temperature of Sanyo LIB under PCM cooling was about $54.4{ }^{\circ} \mathrm{C}$ and decreased about $12.3^{\circ} \mathrm{C}$ compared with natural convection in the $2 \mathrm{C}$ charging and discharging cycles. It was found that the addition of heat dissipation fins could reduce the surface temperature, but the effect was not obvious. In addition, the charge and discharge cycles of the two kinds of LIBs were compared at the discharge rates of $1 \mathrm{C}$ and $2 \mathrm{C}$. Compared with natural convection cooling, the highest temperature of Sanyo LIB with PCM cooling decreased about $4.7^{\circ} \mathrm{C}$ and $12.8^{\circ} \mathrm{C}$ for $1 \mathrm{C}$ and $2 \mathrm{C}$ discharging respectively, and the temperature of Sony LIB highest decreased about $1.1^{\circ} \mathrm{C}$ and $2{ }^{\circ} \mathrm{C}$.
\end{abstract}

Keywords: lithium-ion battery; thermal management; phase change material; temperature; heat dissipation fins; capacity

\section{Introduction}

The ways to deal with the energy crisis and environmental pollution and develop new energy of safety and cleanness have become the focus of the attention of all countries in the world. It also becomes the core issue to solve the sustainable development of humankind. LIBs, which have the advantages of high specific energy, relatively high operating voltage, long cycle life, low self-discharge rate, small and convenient, are considered to be one of the most promising energy storage devices [1-3]. However, if the operating temperature of LIB is high and the heat dissipation is not timely, it will lead to thermal failure, shorten the service life of LIB and cause safety problems, such as fire and explosion $[4,5]$. Therefore, the thermal safety of LIB needs to be focused on.

The temperature difference between battery internal and ambient, as well as the temperature difference between the cells inside the battery pack will have a negative impact on the performance, life and safety of the battery [6]. Therefore, it is necessary to conduct a reasonable heat management system to make the LIB working in the normal operating temperature range [7-10]. At present, there are three kinds of mainstream thermal management methods for LIBs including air cooling, liquid cooling 
and PCM cooling [11]. Air cooling is divided into natural air cooling and forced air cooling. Pesaran et al. studied the air cooling performance of the battery thermal management system (BTMS). The results showed that the air cooling could effectively reduce the battery temperature and keep the battery temperature consistent in a low rate discharging [12]. Giuliano et al. studied the thermal management system using air cooling of metal foam-based heat exchanger plate. The system showed that the LIB temperature decreased with the increase of airflow. However, the thermal conductivity of air is low and the heat dissipation is weak [13]. Compared with the air cooling method, the liquid cooling method has higher thermal conductivity, which leads to higher cooling performance and is more suitable for cooling large battery packs. Liquid cooling is divided into direct and indirect liquid cooling. Chen et al. compared different liquid cooling systems of LIB, and the results showed that the indirect liquid cooling system had the lowest temperature rise and was more practical than direct liquid cooling [14]. Zhang et al. applied the S-type guide plate to the integrated module of liquid cooling heat dissipation system, and found that the device could avoid heat concentration, improve heat transfer performance and keep the temperature of LIB uniform [15]. However, the traditional battery thermal management method that uses cheap air and water as the cooling medium requires additional energy to drive the cooling medium circulation. In battery thermal management applications, the battery's safe operating temperature is often sacrificed at the expense of battery capacity and power in exchange for longer operating life, and these traditional thermal management methods are complex and occupy a large space [16]. In recent years, researchers have found that PCMs exhibit excellent performance in thermal management of LIB $[17,18]$ since they have large storage density apart of many other advantages [19-21]. Duan et al. conducted the numerical and experimental studies on PCM heat transfer, and found that they have great potential in thermal management due to potential energy storage and controllable temperature stability [22]. PCM battery management system which performed better than traditional thermal management system was first proposed and patented by Al-Hallaj and Selman [23,24]. Mills and Al-Hallaj used the entropy coefficient method to simulate the battery pack, and the results showed that using a PCM could significantly improve the system performance and keep the operating temperature below $55^{\circ} \mathrm{C}$, even at high discharge rate [25]. Javani et al. studied the effect of a PCM on LIB, and found that it could make the temperature distribution uniform and keep the battery in a safe temperature range [26]. Weng et al. systematically investigated the cooling behavior and the influence of several detailed factors on the performance of a PCM. The experimental results showed that a PCM module with a thickness of $\sim 10 \mathrm{~mm}$ presented the optimal cooling performance [27]. Javani et al. investigated the heat transfer with a PCM in passive thermal management of electric and hybrid electric vehicles. The results showed that the temperature distribution became about $10 \%$ more uniform when a PCM was applied in a $3 \mathrm{~mm}$ thickness around the cell. The PCM with $12 \mathrm{~mm}$ thickness decreased the maximum temperature about $3.04{ }^{\circ} \mathrm{C}$ [28]. However, it is found that PCM is easy to get heat saturation when absorbing a large amount of heat in the practical application. BTMS based on pure phase-varying materials cannot work for a long time in high-power batteries and effectively control the battery temperature. Commonly used PCM is paraffin wax whose thermal conductivity is very low. The thermal conductivity of PCM is improved by adding high thermal conductivity materials such as expanded graphite, carbon fiber, graphene, aluminum foam, copper foam and so on [29-32].

On the other hand, many researchers combined other cooling methods with PCM-based BTMS in order to improve the cycling stability and thermal management ability $[33,34]$. The complex PCM based BTMS can effectively reduce temperature rise and temperature difference, and maintain battery performance, particularly in extreme environments $[35,36]$. Sun et al. proposed a PCM combined with heat-dissipating fins to enhance the heat transfer. The results showed that the performance of PCM-fin system was better than that of pure PCM system [37]. Azizi et al. used a PCM and composite materials of aluminum mesh plates to carry on the thermal management to the $\mathrm{LiFePO}_{4}$ battery pack under the high temperature environment. The results showed that the usage of PCM and aluminum wire mesh could significantly reduce the surface temperature of the batteries and improve the performance of the battery pack [38]. Although the use of PCM either alone or combined with heat dissipation fins had 
been extensively studied, there is no optimal solution for the best cooling effect, quantity, and price of PCMs used in LIBs at present. The combination of a PCM and heat dissipation fin will inevitably increase the weight of the BTMS device. As far as we know, a PCM with high thermal conductivity in the battery charging and discharging cycles and the optimization of the coexistence system of PCM and heat dissipation fin also needs further research. In this paper, we first tested the cooling effect of a PCM with higher thermal conductivity whose phase change process is a solid-solid phase change, and then designed a new type of heat dissipation fins. The main purpose of this paper is to study the cooling effect of a PCM with high thermal conductivity on the battery and the effect of a PCM combined with a new type of heat dissipation fins with a relatively small volume. The authors conducted the experiments to investigate the temperature and capacity changing of two kinds of batteries under different conditions.

\section{Experiment}

\subsection{Experimental Description}

Experiments were carried out on two different brands of LIB (Sanyo ternary and Sony $\mathrm{LiFePO}_{4}$ battery). The detailed parameters of the batteries were shown in Table 1. The experimental conditions of the battery in extreme conditions (inside the closed aluminum tube), natural convection, pure PCM, and PCM combined with the heat dissipation fins were set up. The experiments were carried out in the carton box (length $\times$ width $\times$ height, $35 \times 20 \times 20 \mathrm{~cm}$ ) for the thermal isolation from environmental influences, and each experimental condition is shown in Figure 1. The aluminum tube size with an inner diameter of $36 \mathrm{~mm}$, the height of $65 \mathrm{~mm}$, and thickness of $6 \mathrm{~mm}$ (provided by Yuezhong Metal Material Co., Ltd., Dongguan, China) was used, and its thermal conductivity is $237.2 \mathrm{~W} / \mathrm{m} \cdot \mathrm{K}$. Figure $1 \mathrm{~d}$ shows that the fin is composed of two circular fins and three vertical fins. Its material is tin sheet and the thermal conductivity is $150 \mathrm{~W} / \mathrm{m} \cdot \mathrm{K}$. The design of the fin structure is followed by: (1) The ring is set at the bottom of the battery and in the middle of the battery respectively as the temperature of the middle and low part of the battery is higher. (2) The vertical fin protruding is designed to disperse the generated heat in time and reduce the temperature effect. (3) According to previous studies, the best results are obtained when the distance between the radiator and the battery is 0.2 times the diameter of the battery [39]. So, the circular heat dissipation fin size (outer diameter $\times$ inner diameter $\times$ height) is $\varphi 26 \times \varphi 22 \times 4 \mathrm{~mm}$, vertical heat dissipation fin size (length $\times$ width $\times$ height) is $4 \times 2 \times 80 \mathrm{~mm}$.

The high thermal conductivity phase change composites with phase change temperature of $52{ }^{\circ} \mathrm{C}$ (provided by Zhongjia New Material Technology Co., Ltd., Guangzhou, China) were selected due to the higher thermal conductivity than the pure paraffin. In this experiment, the phase change material is wrapped around the battery with a thickness of $9 \mathrm{~mm}$ and a weight of about $9.9 \mathrm{~g}$. The main components are phase change wax and expanded graphite, which have the following advantages: solid-solid phase change, high phase change latent heat, insulation, good cycle stability, non-corrosive, and non-toxic. Detailed thermal physical properties are shown in Table 2.

Table 1. Detailed battery parameters.

\begin{tabular}{ccc}
\hline Battery Type & Sanyo Lithium-Ion Battery & Sony Lithium-Ion Battery \\
\hline Capacity & $2600 \mathrm{mAh}$ & $1100 \mathrm{mAh}$ \\
Voltage $(\mathrm{V})$ & $3.7 \mathrm{~V}$ (Discharge cut-off voltage $3.0 \mathrm{~V}$, & $3.2 \mathrm{~V}$ (Discharge cut-off voltage $2.0 \mathrm{~V}$, \\
The maximum charging voltage is $4.2 \mathrm{~V}$ & The maximum charging voltage is $3.6 \mathrm{~V}$ ) \\
Life (seconds) & $\Phi 18 \times 65 \mathrm{~mm}$ & $\Phi 18 \times 65 \mathrm{~mm}$ \\
Anode material & 1000 & 1000 \\
\hline
\end{tabular}




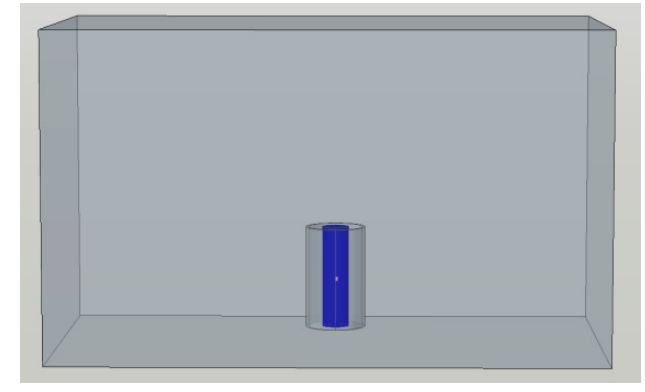

(a) Extreme conditions (charge/discharge inside the closed aluminum tube)

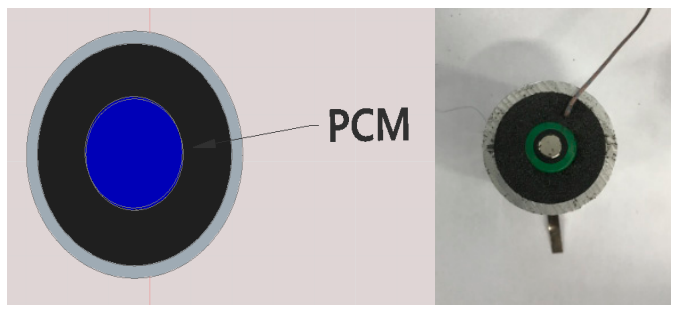

(c) Phase change material cooling

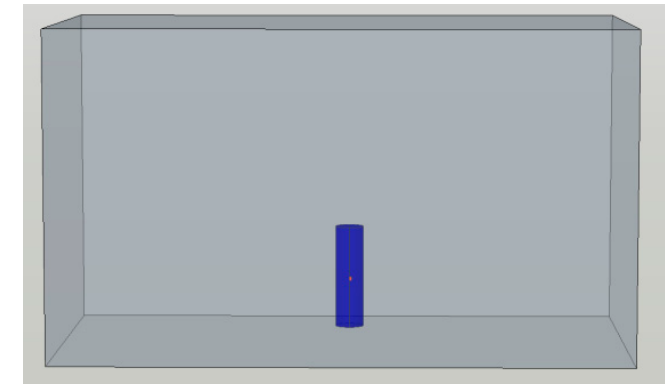

(b) Natural convection cooling

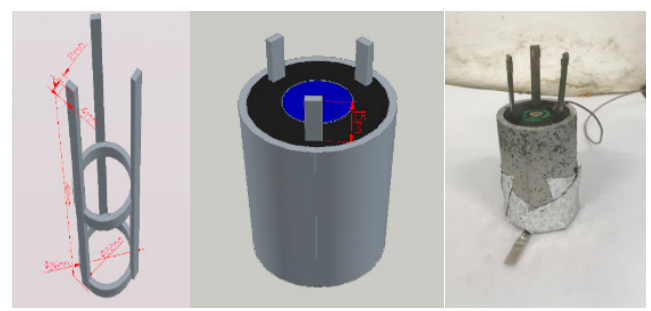

(d) Heat dissipation fins, pcm-fin cooling

Figure 1. Experimental conditions

Table 2. Thermal physical properties of PCM.

\begin{tabular}{cc}
\hline Thermal Physical Characteristic & Parameters \\
\hline Phase change temperature $\left({ }^{\circ} \mathrm{C}\right)$ & $52 \sim 55$ \\
Thermal conductivity $(\mathrm{W} / \mathrm{m} \cdot \mathrm{K})$ & 3 \\
Latent heat of phase change $(\mathrm{J} / \mathrm{g})$ & 170 \\
Specific heat capacity $\left(\mathrm{J} / \mathrm{kg} \cdot{ }^{\circ} \mathrm{C}\right)$ & 1.8 \\
Density $\left(\mathrm{g} / \mathrm{cm}^{3}\right)$ & 0.2 \\
Materials & Phase change wax, Expanded graphite \\
\hline
\end{tabular}

\subsection{Experimental Facility}

Figure 2 shows the schematic diagram of the experiments. The LIB charging and discharging instrument (provided by Neware Electronics Co., Ltd., Shenzhen, China) is provided for the LIB normal charging and discharging cycles, and the accuracy and stability of the whole range can reach $0.1 \%$. The LIB temperature was measured by T-type thermocouples (provided by OMEGA), and recorded by the temperature data acquisition unit (provided by National Instruments) as shown in Figure 2. According to the factory temperature check, the thermocouple temperature measurement accuracy is controlled within $0.5^{\circ} \mathrm{C}$. The thermocouple is patch type, which is attached to the middle of the battery surface. The PCM is wrapped around the battery, and the thermocouple is embedded in the PCM. The thermocouple was calibrated before the experiments. The temperature of the LIB by thermocouple was measured only to analyze the cooling effect of PCM on the LIB, not to study the internal reaction of the LIB in this study. Hence, the T-type thermocouple is attached to the center position of the batteries surface to measure the optimum temperature. 


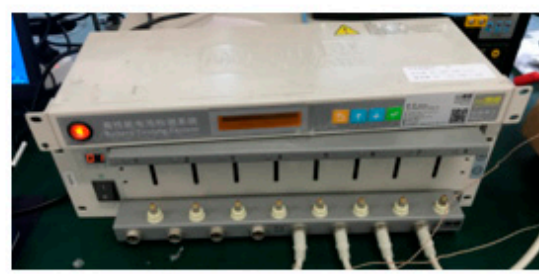

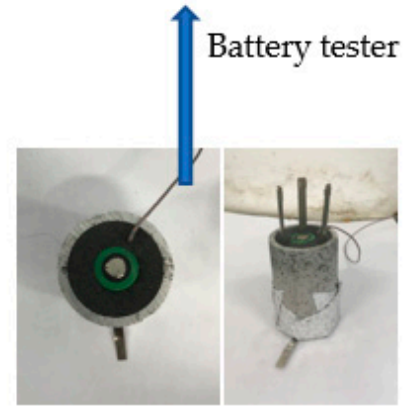

Batteries module
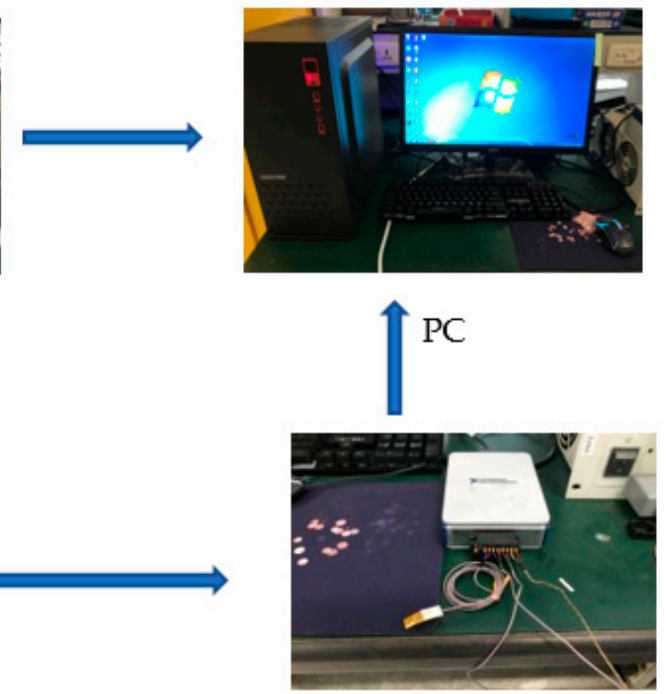

Temperature date logger

Figure 2. Schematic diagram of the experiment.

Before the experiment, the LIBs were discharged to the cut-off voltage, charged to maximum voltage, and then placed $24 \mathrm{~h}$ to keep the LIB stable. The temperature in the carton is $25^{\circ} \mathrm{C}$, and its environmental temperature error is controlled within the normal range of $0.5^{\circ} \mathrm{C}$. The charge and discharge process of the two batteries are shown in Table 3. The cycle of Sanyo LIB can be divided into four stages: (1) discharge stage, with $2 \mathrm{C}$ constant current discharge to $2.5 \mathrm{~V}$. (2) shelving stage for $5 \mathrm{~min}$. (3) charging stage with $1 \mathrm{C}$ constant current and voltage to $4.2 \mathrm{~V}$. (4) shelving stage with $5 \mathrm{~min}$. The Sony LIB is tested in the same charge-discharge cycle as the Sanyo LIB. The only differences are the cutoff discharging voltage of $2.0 \mathrm{~V}$ and cutoff charging voltage of $3.6 \mathrm{~V}$ because of its relatively small capacity and voltage. Besides, two kinds of cells are placed in the PCM to discharge at a discharge rate of $1 \mathrm{C}$ and $2 \mathrm{C}$.

Table 3. Design of charging and discharging experimental conditions.

\begin{tabular}{|c|c|c|c|c|c|}
\hline \multirow[b]{2}{*}{ Processing } & \multirow[b]{2}{*}{ Condition } & \multicolumn{2}{|c|}{ Current (A) } & \multicolumn{2}{|c|}{ Voltage (V) } \\
\hline & & Sanyo Battery & Sony Battery & Sanyo Battery & Sony Battery \\
\hline $\begin{array}{l}\text { Discharging } \\
\text { shelving }\end{array}$ & $\begin{array}{c}\text { Constant current } \\
5 \mathrm{~min}\end{array}$ & $2.6(1 \mathrm{C}), 5.2(2 \mathrm{C})$ & $1(1 \mathrm{C}), 2(2 \mathrm{C})$ & 4.2 & 3.6 \\
\hline $\begin{array}{l}\text { Charging } \\
\text { shelving }\end{array}$ & $\begin{array}{l}\text { Constant voltage } \\
\text { and current } \\
5 \mathrm{~min}\end{array}$ & $2.6(1 C)$ & $1(1 \mathrm{C})$ & 2.5 & 2.0 \\
\hline
\end{tabular}

\section{Results and Discussions}

\subsection{Temperature Change during LIB Cycle}

When the LIB is charging and discharging, the reaction occurs inside the LIB, which produces heat and shows the increase of battery temperature. Figure 3 shows the temperature change during charging and discharging of Sanyo LIB under four different working conditions: extreme conditions, natural convection cooling, PCM cooling, and PCM combined with heat dissipation fins cooling at the ambient temperature of $25^{\circ} \mathrm{C}$. Figure 3a shows the temperature curve of LIB in two cycles. That can be seen from the figure, the temperature of LIB in the enclosed space rises from $30^{\circ} \mathrm{C}$ to about $77.3^{\circ} \mathrm{C}$ during discharging, which obviously exceeds the normal operating temperature of the battery. The high temperature has certain bad influence on the LIB. The long-term working under the extreme condition will cause the LIB internal electrolyte decomposition, the positive and negative electrode reaction, 
and so on, which may cause the LIB thermal runaway and produce the safety risks. The highest temperature of the LIB is about $54.5^{\circ} \mathrm{C}$ under PCM cooling, $66.2^{\circ} \mathrm{C}$ under natural convection, $77.3^{\circ} \mathrm{C}$ under extreme condition. Compared to the air cooling, the temperature of LIB using PCM cooling has a much smaller increase rate, and the highest temperature drops by $11.7^{\circ} \mathrm{C}$. Therefore, the results show that PCM can absorb some heat during the LIB discharging process, effectively reducing the LIB temperature. For the analysis of the cooling condition of the PCM with heat dissipation fins on the LIB, the heat dissipation fins have been adopted. The volume ratio of PCM and heat dissipation fins in the device is about $96 \%: 4 \%$. According to the diagram, the maximum temperature difference between the LIB in this working condition and PCM cooling condition is about $0.2^{\circ} \mathrm{C}$. The combination of heat dissipation fins can slightly reduce the temperature of LIB. The reason may be the fin structure cannot dissipate the latent heat in time due to its small volume ratio. In the research on the combination of PCM with heat dissipating fins, while giving full play to the maximum effect of heat dissipating fins, its cost and influence on the whole LIB structure should also be considered. Javani et al. [28] investigated heat transfer with PCMs in passive thermal management of electric and hybrid electric vehicles. Their results showed that the temperature distribution became about $10 \%$ more uniform when the PCM was applied in a $3 \mathrm{~mm}$ thickness around the LIB. The PCM with $12 \mathrm{~mm}$ thickness decreased the maximum temperature about $6.6^{\circ} \mathrm{C}$. In this research, the PCM not only has better cooling performance, but also makes the device having the advantages of small size and lightweight. In addition, the PCM in this study has a solid-solid phase change process, which avoids the liquid leakage. The device structure in this study is simpler and more practical, which may has a potential for commercialization.

Figure $3 \mathrm{~b}$ shows the temperature change curve of LIB during six cycles. The temperature of LIB tends to be stable under various working conditions. However, the average of the maximum temperatures for the six cycles of $\mathrm{LIB}$ reaches about $77.8^{\circ} \mathrm{C}$ in the enclosed space, which is in an unsafe state. It may cause great damage to the internal structure of the LIB and seriously affect the cycle service life of LIB. The PCM can have a good cooling effect on the temperature and make the average of the maximum temperatures for the six cycles of LIB keep at about $54.4^{\circ} \mathrm{C}$. The average of the maximum temperatures for the six cycles of LIB under the experimental condition of the combination of PCM and heat dissipating fins is about $54.3^{\circ} \mathrm{C}$, which is not significantly different compared to PCM cooling condition. The result shows that the effect of heat dissipation fins is not significant and the pure PCM cooling is the best choice due to the cost and complexity of the device structure. On the other hand, the LIB temperature rose at a slower rate and the temperature curve shifted slightly to the right as the cycle progressed. The heat generated inside LIB consisted of five parts: electrochemical reaction heat, ohmic internal resistance heat, polarization heat, electrolytic decomposition heat, and SEI decomposition heat. The electrolytic and SEI decomposition heat were very small and could be ignored when LIB was in the normal operating temperature range. The LIB would produce heat during the charging and discharging cycles. For discharging condition, the total chemical reaction was an exothermic reaction and the temperature rose theoretically, and for charging condition, the total chemical reaction was an endothermic reaction and the temperature drops theoretically. However, in the case of natural convection in Figure 3b, the temperature remains unchanged or even rises within a short period of time (region A) during the battery charging process. In the LIB charge process, although it is an endothermic process, the LIB generated heat such as ohmic internal resistance heat, polarization internal resistance heat, and electrochemical reaction heat more than itself heat dissipation, so that the temperature remains stable or even slightly rises. 


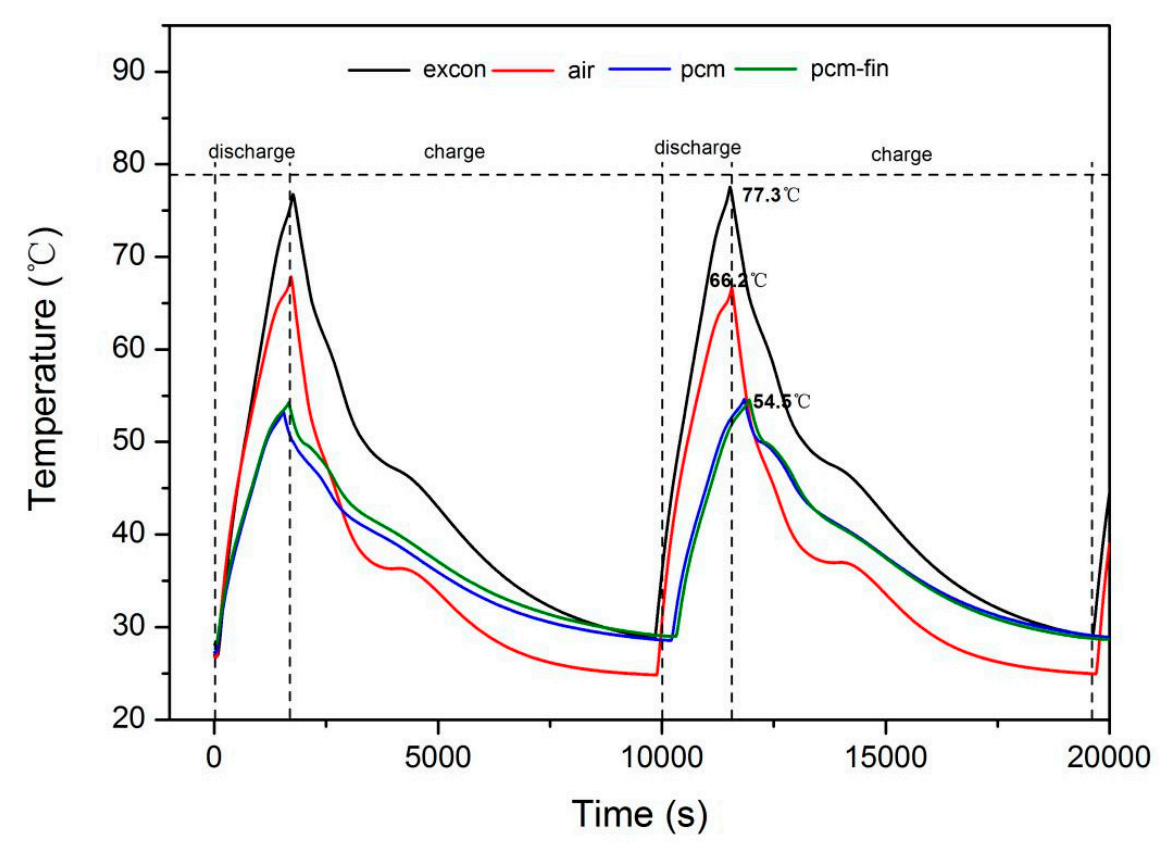

(a) Change of charging and discharging temperature of Sanyo LIB

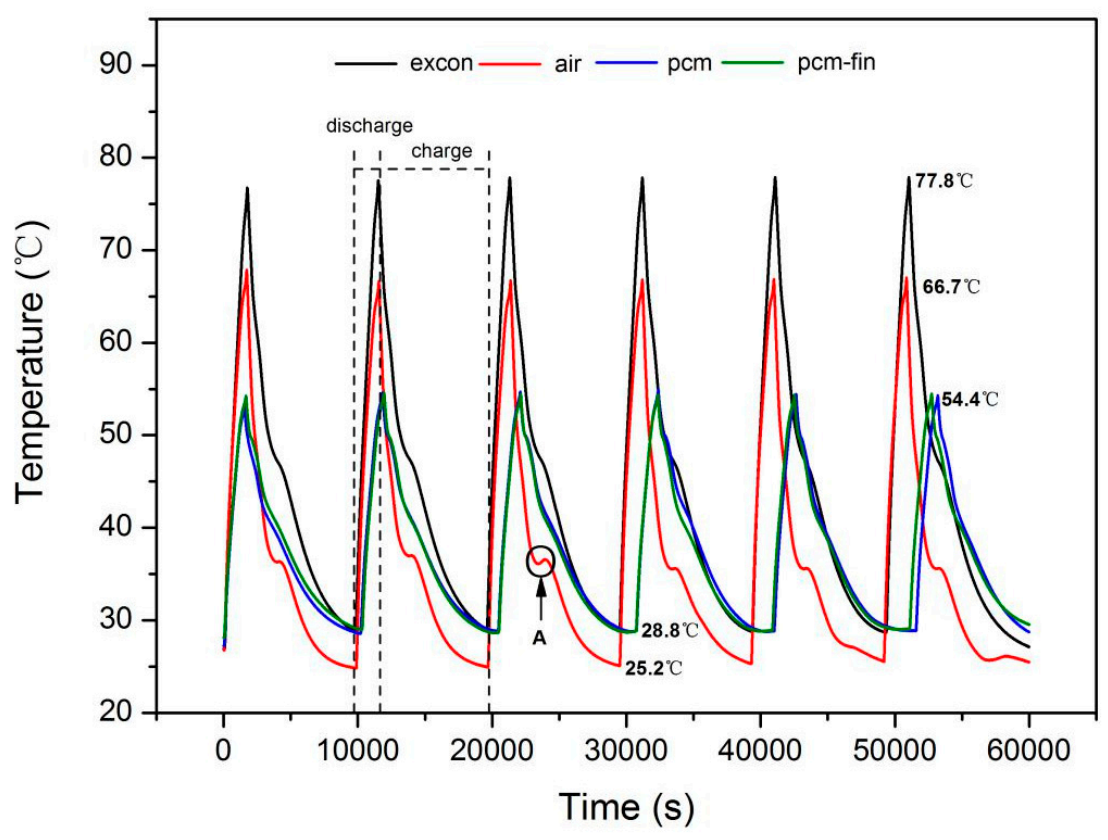

(b) The temperature changing of Sanyo LIB cycle

Figure 3. The temperature changing of LIBs during charging and discharging.

Figure 4 shows the temperature changes of $\mathrm{LiFePO}_{4}$ battery in charging and discharging cycles under four different working conditions. It can be found that the highest temperature of the LIB under extreme conditions is about $40.6^{\circ} \mathrm{C}$ and the lowest temperature is about $35.1^{\circ} \mathrm{C}$ when the LIB is shelved after charging. The temperature of $\mathrm{LiFePO}_{4} \mathrm{LIB}$ will not be too high compared with Sanyo LIB when it works for a short time under extreme conditions due to its smaller LIB capacity, and lower internal polarization and ohmic resistance heat. The maximum temperature of Sony LIB is about $35.1^{\circ} \mathrm{C}$ under PCM cooling, $37.5{ }^{\circ} \mathrm{C}$ under natural convection, $40.6{ }^{\circ} \mathrm{C}$ under extreme condition. It is found that 
the LIB temperature under PCM cooling decreases by $2.4^{\circ} \mathrm{C}$ compared with the natural convection. In the case of the combination of PCM and heat dissipation fins, the temperature decreases $0.4{ }^{\circ} \mathrm{C}$ than PCM cooling due to the temperature of battery itself is low. In addition, the Sony LIB temperature in extreme conditions cannot be lowered to the level of other conditions during charging and shelving due to the heat is not dispersed in time. It can accelerate the degradation of the LIB and influence the LIB performance in extreme condition for a long time, which further prove the necessity of BTMS.

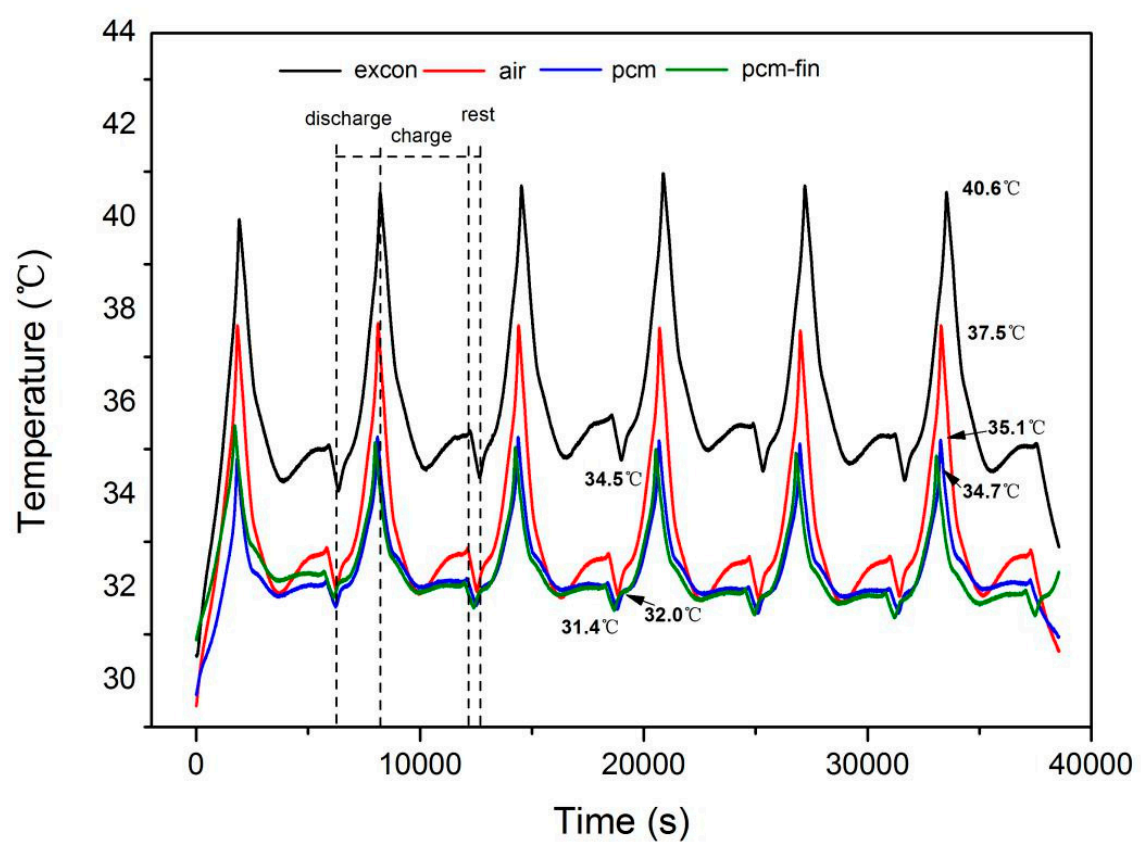

Figure 4. The temperature changes of $\mathrm{LiFePO}_{4}$ battery during charging and discharging.

\subsection{The Influence of Temperature on Battery Performance}

Temperature is an important factor affecting battery performance parameters. Too high or low temperature will affect LIB capacity, charging and discharging efficiency, safety performance and result in battery performance degradation. Figure 5a shows the current change of the LIB in the charging and discharging cycle, and Figure $5 \mathrm{~b}$ shows the voltage change. For the convenience of statistics, the $\mathrm{x}$-coordinate in the figure represents the time step, and each step is $10 \mathrm{~s}$. That can be seen from the figures, the current and voltage curves of the LIB have the same trend in each working condition. The current and voltage can reach the set rating in each charging and discharging cycle. However, as the cycles progresses, compared with the LIB under extreme conditions, the LIB curves in other conditions shift to the right, which is very similar to Figure $3 \mathrm{~b}$. The reason is related to the battery charging and discharging time. Under constant current conditions, the total flux of lithium ions should be roughly similar (both as diffusion in the electrolyte, and total flux into and out of the active material particles), and environmental conditions have little effect on it. However, at lower temperatures, a higher concentration gradient is required to overcome the slower diffusivity to meet the required flux. The higher concentration gradient leads to higher over potential and uneven utilization of electrodes. In turn, this leads to faster reaching of the cut-off voltage when working at lower temperatures. It can be clearly seen in Figure 5a that the LIBs in PCM and PCM-Fin cooling experiments seem to be faster reaching the cutoff voltage than the extreme condition and air cooling experiments in the first discharge cycle when all batteries start at the same state of charge (SOC). On the contrary, a higher temperature of LIB means that a constant current can be provided for a longer period of time. That can be seen in Figure $5 b$, the voltage drop of LIBs at higher temperature is smaller. In addition, according to Figure 3 , it is found that in the constant current charging stage of the battery, the temperature of the battery decreased rapidly in the extreme condition and air cooling experiments, and the temperature is lower 
than the other cases in a period of time due to the latent heat effect of PCM. It seems that the LIBs under PCM and PCM-Fin cooling conditions can be charged for a longer time in the later cycles than the other cases.

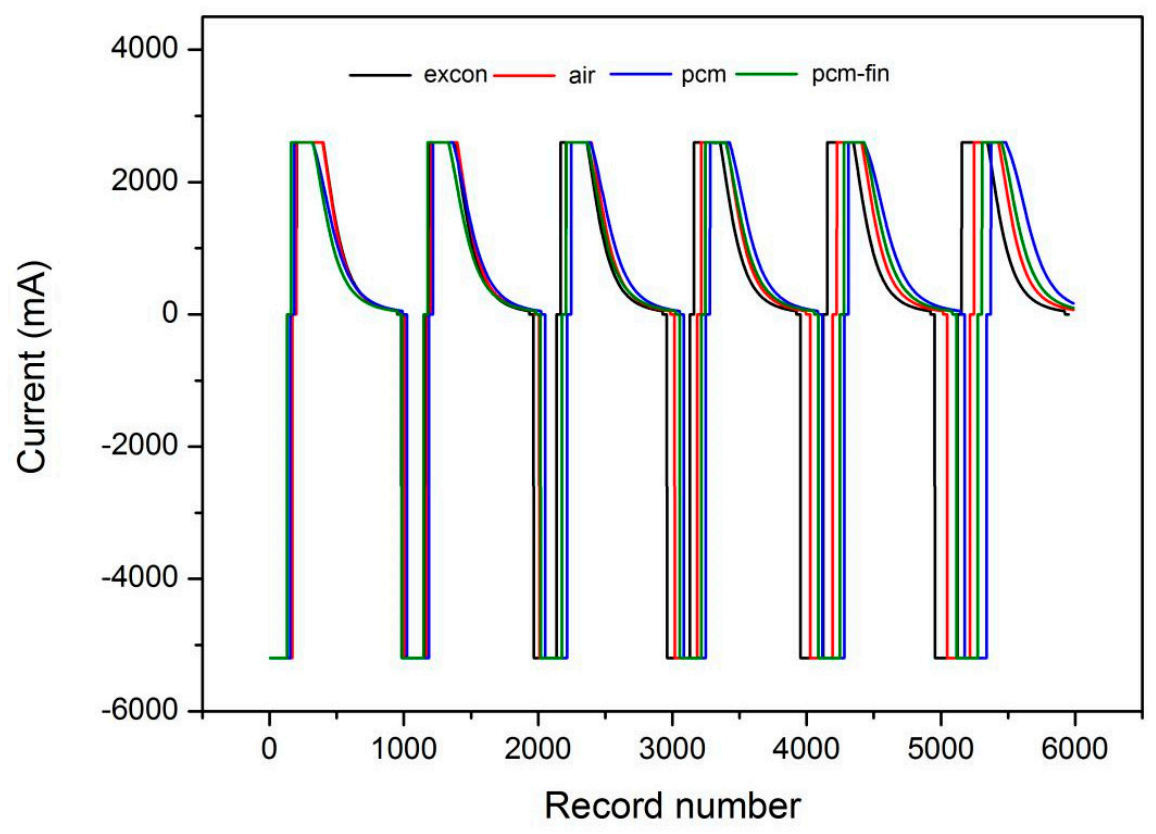

(a) Current curves

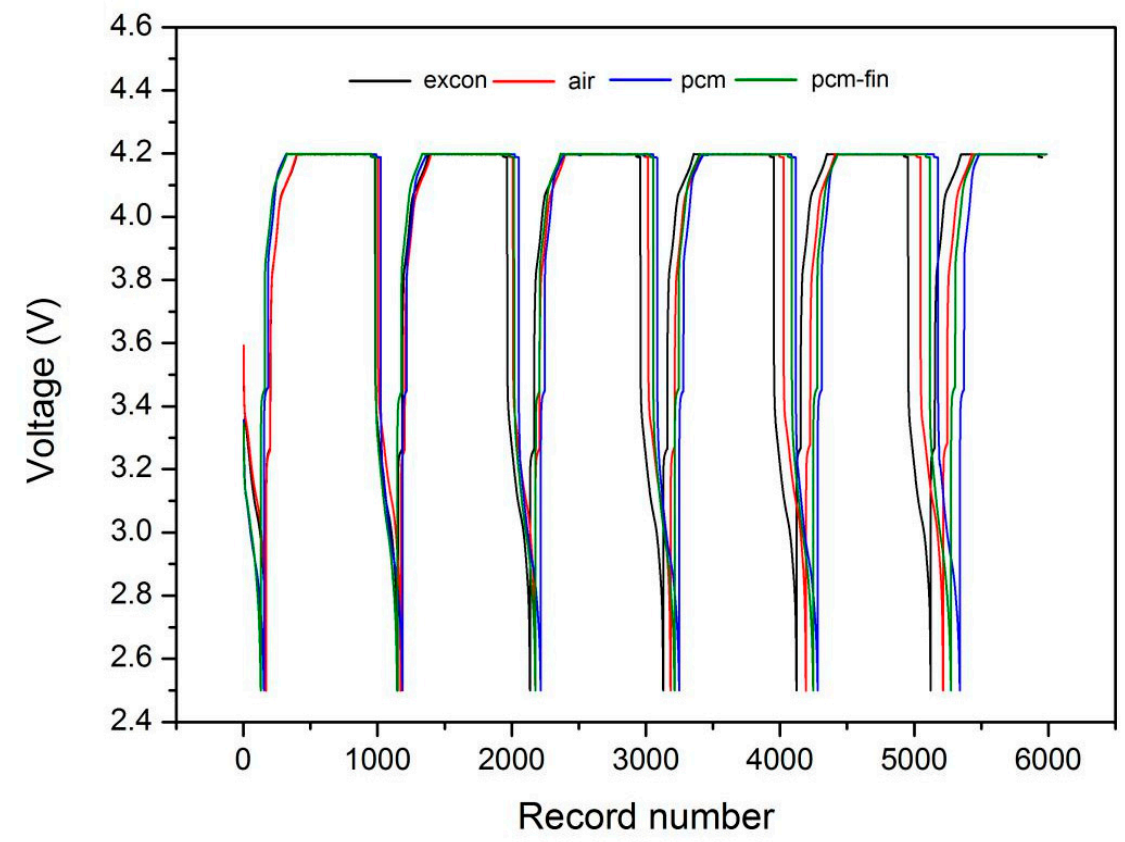

(b) Voltage curves

Figure 5. The current and voltage curves of Sanyo LIB.

Figure 6 shows the current and voltage changes in the $\mathrm{LiFePO}_{4}$ battery during charging and discharging cycles. The current and voltage changes of $\mathrm{LiFePO}_{4} \mathrm{LIB}$ have the same trend under four different working conditions. Since the operating temperature of $\mathrm{LiFePO}_{4} \mathrm{LIB}$ under four working 
conditions is around $30-40^{\circ} \mathrm{C}$, the LIB is in a normal working state and its current and voltage will not change much.

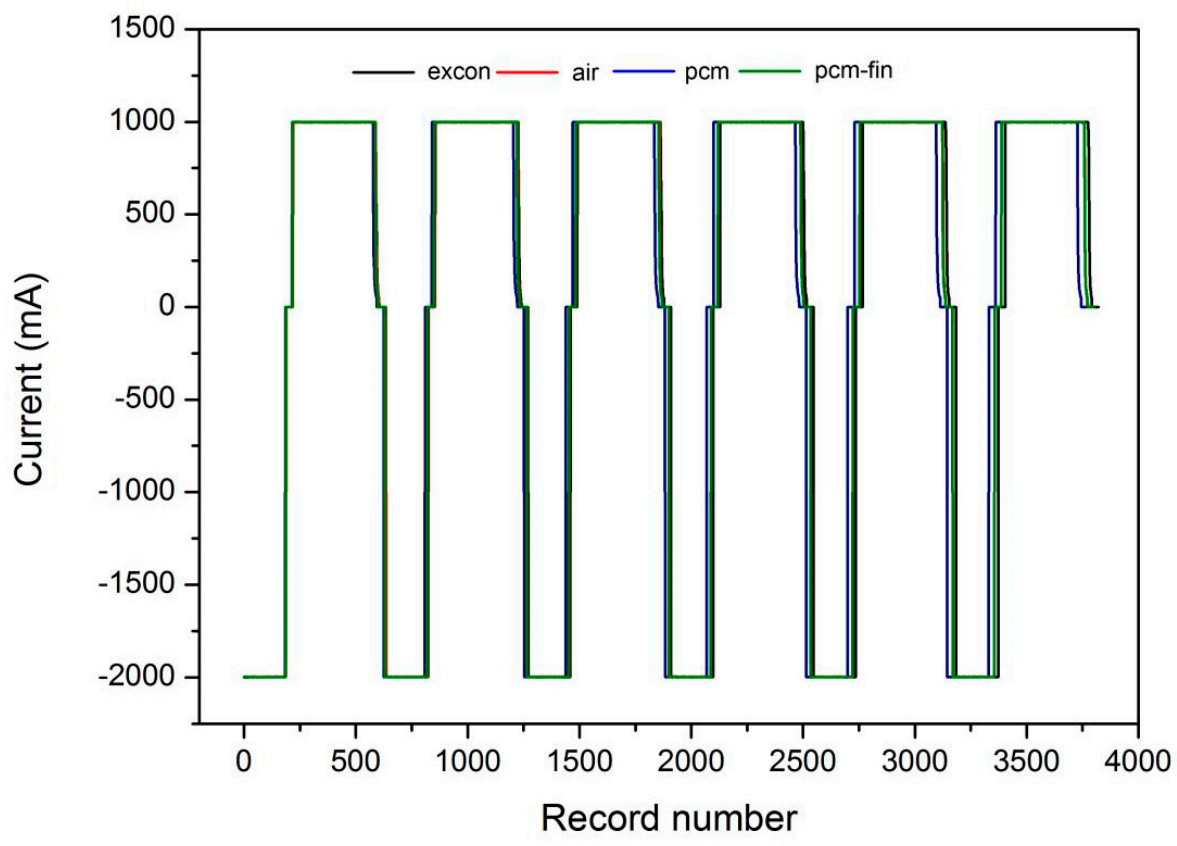

(a) Current curves

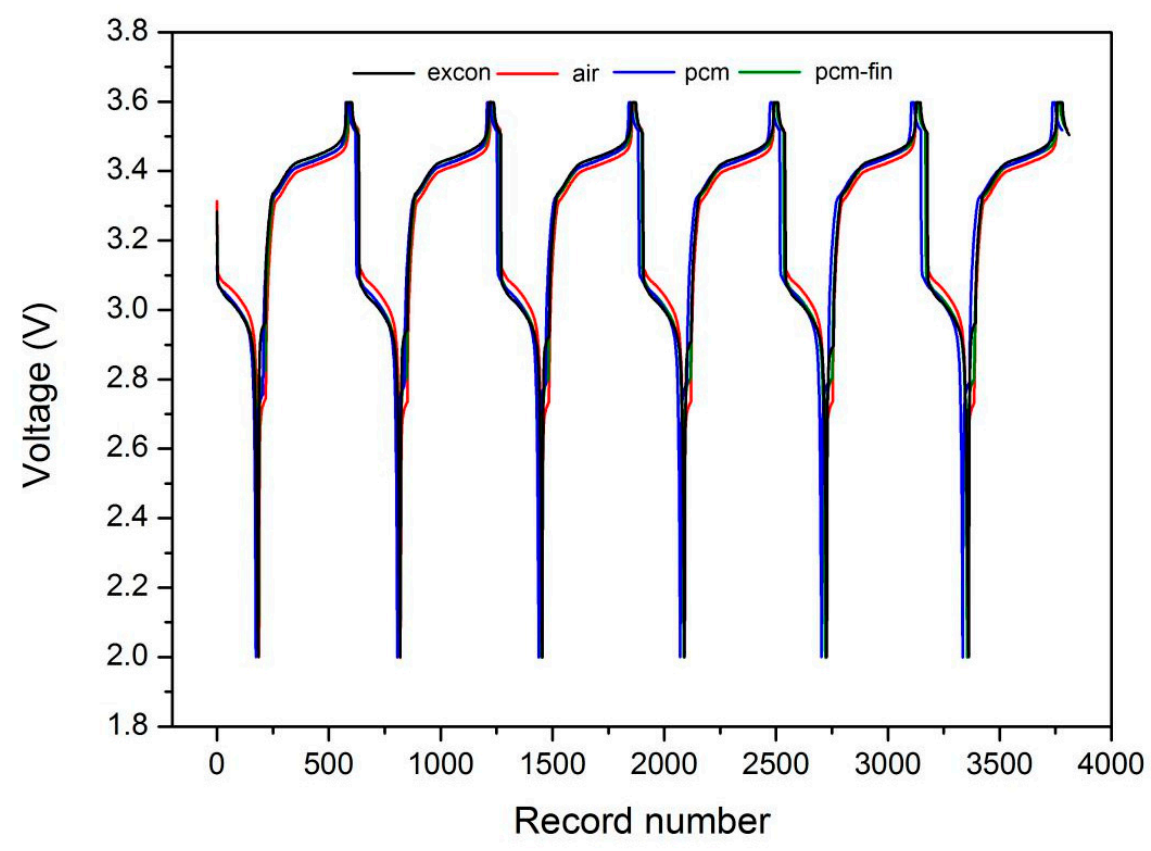

(b) Voltage curves

Figure 6. The current and voltage curves of Sony LIB.

Table 4 shows the capacity changes of Sanyo LIB charging and discharging cycles under different working conditions. It is found from the table that the LIB capacity has some changes in each working cycle. The average charging capacity of six cycles is $2414.6 \mathrm{mAh}$ under the extreme conditions, 2399.4 mAh under natural convection, 2397.7 mAh under PCM cooling, and 2403.6 mAh under PCM combined with heat dissipation fins working condition. The average discharging capacity of six cycles 
is $2412.7 \mathrm{mAh}$ under the extreme conditions, $2398.3 \mathrm{mAh}$ under natural convection, $2398.4 \mathrm{mAh}$ under PCM cooling, and $2383.3 \mathrm{mAh}$ under PCM combined with heat dissipation fins working condition. Table 5 shows the capacity changes of $\mathrm{LiFePO}_{4}$ battery charging and discharging cycles under different working conditions. The average charging capacity of six cycles is 1022.6, 1034.9, 1031.6, and 1034.5 mAh, and the average discharging capacity is 1026.8, 1035.9, 1030.4, and 1032.1 $\mathrm{mAh}$, under the extreme conditions, natural convection, PCM cooling, and PCMcombined with heat dissipation fins working condition, respectively. The LIB capacity changes are related to the temperature. The battery capacity does not change significantly, which indicated that the LIB capacity is not significantly affected by short cycles even at high temperatures. Compared with the natural convection condition, the LIB discharging capacity under PCM cooling and PCM combined with heat dissipation fins decreased slightly. In the case of higher temperature, the battery reaches the cut-off voltage more slowly during the charging and discharging process, and the constant current charging and discharging time is longer, so the charging and discharging efficiency is higher, and the maximum capacity value is larger. However, the high temperature has a great influence on the capacity degradation rate of LIB [40]. The higher temperature leads to a quicker rate of various side reactions in the battery and faster the capacity degradation. Due to the low number of battery cycles in the experiments, the internal damage or possible side reactions that might have occurred at high temperatures had not yet become apparent. In the current application of LIB with the high efficiency and capacity, reducing the impact of itself side reaction and temperature are particularly critical, which is also a hurdle for the current LIB technology breakthrough.

Table 4. Capacity curve of Sanyo LIB in charge and discharge cycles.

\begin{tabular}{|c|c|c|c|c|c|c|c|c|}
\hline \multirow{3}{*}{$\begin{array}{l}\text { Sanyo } \\
\text { Battery } \\
\text { Cycles }\end{array}$} & \multicolumn{2}{|c|}{ Excon } & \multicolumn{2}{|c|}{ Air } & \multicolumn{2}{|c|}{ PCM } & \multicolumn{2}{|c|}{ PCM-fin } \\
\hline & \multirow{2}{*}{$\begin{array}{c}\text { Charging } \\
\text { Capacity } \\
\text { (mAh) }\end{array}$} & \multicolumn{2}{|c|}{ DischargingCharging } & \multirow{2}{*}{$\begin{array}{c}\text { Charging } \\
\text { Capacity } \\
\text { (mAh) }\end{array}$} & \multirow{2}{*}{$\begin{array}{c}\text { Charging } \\
\text { Capacity } \\
\text { (mAh) }\end{array}$} & \multirow{2}{*}{$\begin{array}{c}\text { Charging } \\
\text { Capacity } \\
\text { (mAh) }\end{array}$} & \multirow{2}{*}{$\begin{array}{c}\text { Charging } \\
\text { Capacity } \\
\text { (mAh) }\end{array}$} & \multirow{2}{*}{$\begin{array}{c}\text { Charging } \\
\text { Capacity } \\
\text { (mAh) }\end{array}$} \\
\hline & & $\begin{array}{c}\text { Capacity } \\
\text { (mAh) }\end{array}$ & $\begin{array}{c}\text { Capacity } \\
\text { (mAh) }\end{array}$ & & & & & \\
\hline 1 & & & & & 2 & & 5 & 14 \\
\hline 2 & $\$ 3$ & 2412 & 239 & 23 & 86 & 8 & 35 & 632 \\
\hline 3 & 2414.601 & 2413.030 & 2401.894 & 2400.978 & 2402.126 & 2379.272 & 2405.866 & 2384.824 \\
\hline 4 & 2413.782 & 2412.072 & 2395 & 2399.563 & 2396.722 & 2382.227 & 2405.228 & 2386.124 \\
\hline 5 & 2414.819 & 2413.401 & 2401.893 & 2396.380 & 2395.279 & 2384.336 & 2403.516 & 2378.967 \\
\hline 6 & 2412.173 & 2411.815 & 2400.974 & 2397.655 & 2393.280 & 2376.504 & 2402.460 & 2382.489 \\
\hline
\end{tabular}

Table 5. Capacity curve of $\mathrm{LiFePO}_{4} \mathrm{LIB}$ in charge and discharge cycles.

\begin{tabular}{ccccccccc}
\hline \multirow{2}{*}{$\begin{array}{c}\text { Sony } \\
\text { Battery } \\
\text { Cycles }\end{array}$} & \multicolumn{2}{c}{ Excon } & \multicolumn{2}{c}{ Air } & \multicolumn{2}{c}{ PCM } & \multicolumn{2}{c}{ PCM-fin } \\
\cline { 2 - 9 } & $\begin{array}{c}\text { Charging } \\
\text { Capacity } \\
\text { (mAh) }\end{array}$ & $\begin{array}{c}\text { DischargingCharging } \\
\text { Capacity } \\
\text { (mAh) }\end{array}$ & $\begin{array}{c}\text { Capacity } \\
\text { (mAh) }\end{array}$ & $\begin{array}{c}\text { Charging } \\
\text { Capacity } \\
\text { (mAh) }\end{array}$ & $\begin{array}{c}\text { Charging } \\
\text { Capacity } \\
\text { (mAh) }\end{array}$ & $\begin{array}{c}\text { Charging } \\
\text { Capacity } \\
\text { (mAh) }\end{array}$ & $\begin{array}{c}\text { Charging } \\
\text { Capacity } \\
\text { (mAh) }\end{array}$ & $\begin{array}{c}\text { Charging } \\
\text { Capacity } \\
\text { (mAh) }\end{array}$ \\
\hline 1 & 1031.890 & 1032.637 & 1035.779 & 1033.977 & 1032.103 & 1031.853 & 1035.741 & 1024.440 \\
2 & 1008.673 & 1018.444 & 1033.233 & 1035.806 & 1032.359 & 1028.684 & 1031.933 & 1033.147 \\
3 & 1018.732 & 1023.337 & 1034.633 & 1036.101 & 1030.632 & 1029.485 & 1034.568 & 1033.514 \\
4 & 1022.702 & 1026.527 & 1035.109 & 1036.212 & 1031.216 & 1030.508 & 1035.078 & 1033.570 \\
5 & 1025.826 & 1028.784 & 1035.155 & 1036.361 & 1031.566 & 1030.718 & 1034.831 & 1033.665 \\
6 & 1028.002 & 1030.793 & 1035.320 & 1036.645 & 1031.840 & 1031.291 & 1035.110 & 1034.102 \\
\hline
\end{tabular}

\subsection{The PCM Influence on LIB Temperature under Different Discharging Ratios}

Figure 7 shows the temperature curves of Sanyo and Sony LIB under the conditions of natural convection and PCM cooling. It is found that the PCM has a good effect to decrease the LIB temperature no matter it is discharged at a rate of $1 \mathrm{C}$ or $2 \mathrm{C}$. Compared with natural convection cooling, the highest temperature of Sanyo LIB decreases about $4.7^{\circ} \mathrm{C}$ and $12.8^{\circ} \mathrm{C}$ for $1 \mathrm{C}$ and $2 \mathrm{C}$ discharging, respectively, and the highest temperature of Sony LIB decreases about $1.1^{\circ} \mathrm{C}$ and $2{ }^{\circ} \mathrm{C}$. The temperature reduction 
effect of PCM on high rate discharge LIB is more obvious. In the charging and discharging cycles, Sanyo LIB generates more heat due to its large capacity, and PCM absorbs more latent heat. The PCM has the most obvious effect on the Sanyo battery in a $2 \mathrm{C}$ discharging rate among all experiments.

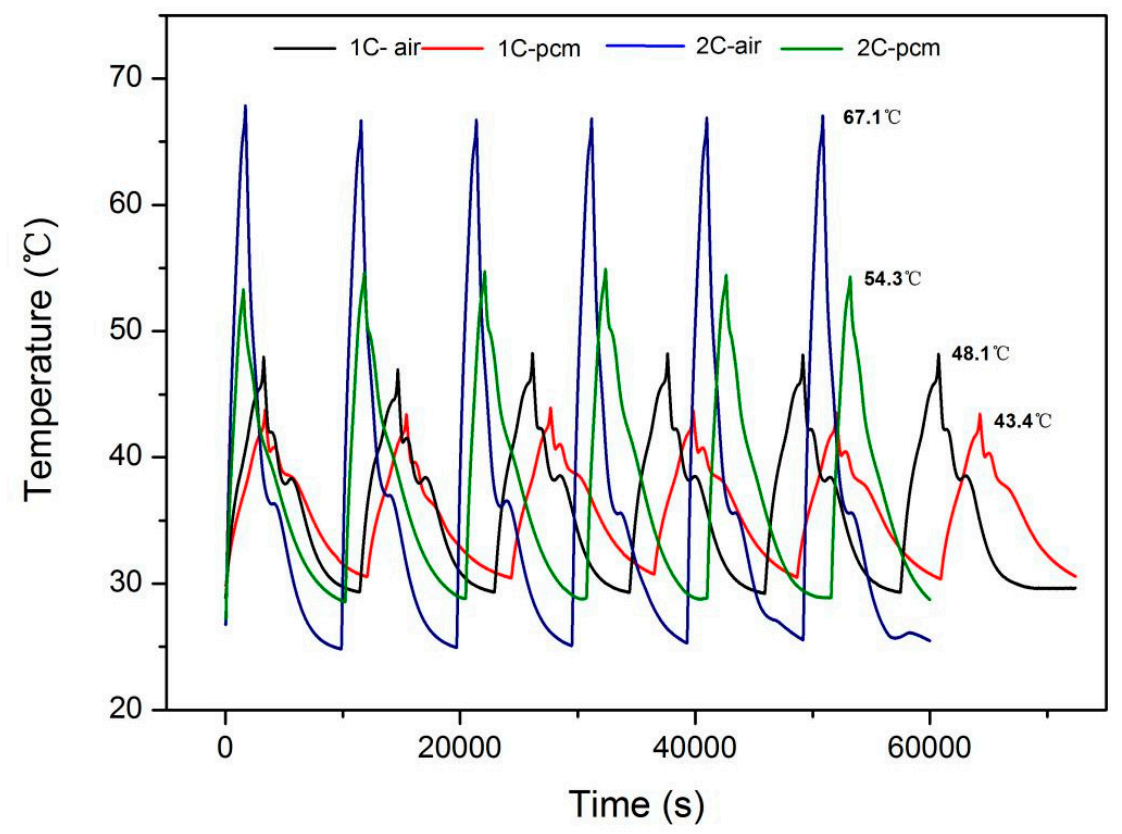

(a) The temperature curves of Sanyo LIB

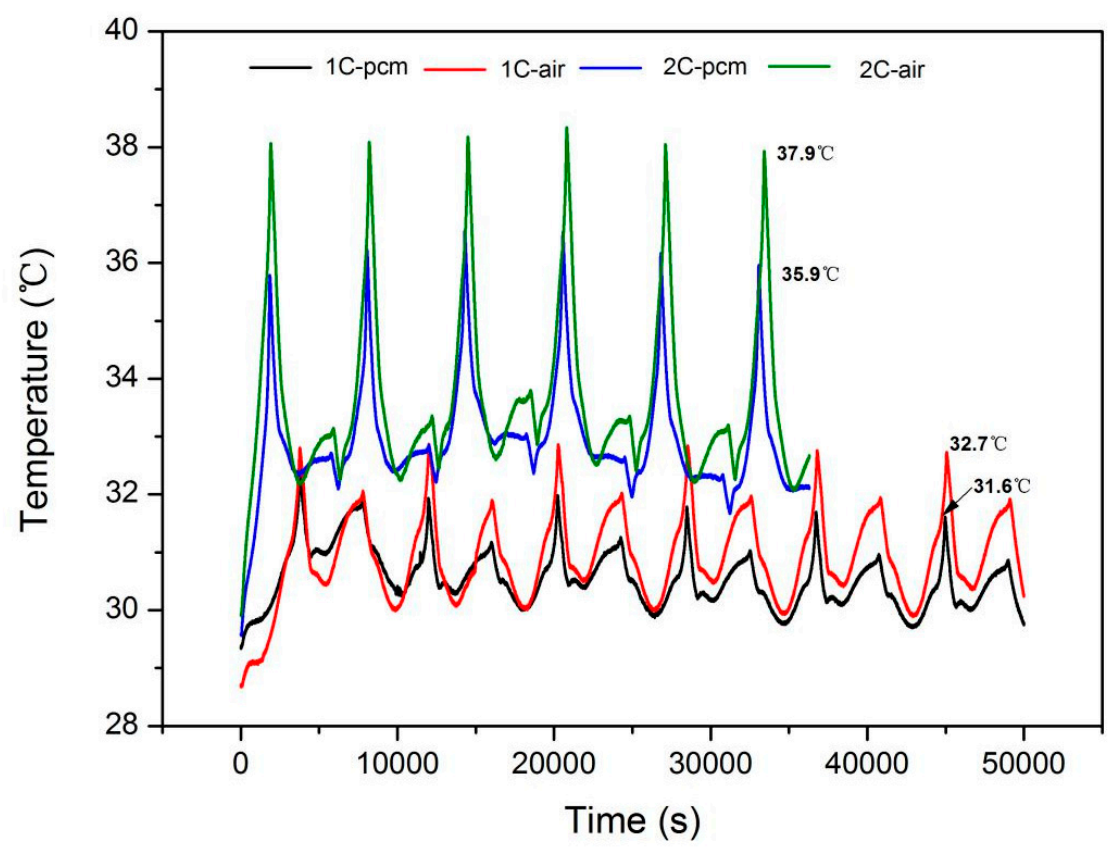

(b) The temperature curves of Sony LIB

Figure 7. The temperature curves of Sanyo and Sony LIB under 1 C, 2 C discharging.

\section{Conclusions}

PCM has been widely used in the thermal management of LIB due to itself advantages. In this paper, the changes of LIB temperature and capacity under different working conditions and discharge 
ratios are analyzed in order to further analyze the PCM influence of LIB thermal management and design an effective BTMS. The conclusions are as follows:

(1) The LIB temperature rises during the discharge process, and the PCM can effectively reduce the LIB temperature and keep its capacity stable. The average highest temperature of Sanyo LIB under the PCM cooling is about $54.4^{\circ} \mathrm{C}$ in the $2 \mathrm{C}$ discharge rate especially, and it is about $12.3^{\circ} \mathrm{C}$ decrease compared with the natural convection cooling.

(2) The heat dissipation fins can reduce the LIB temperature, but the current effect is not very significant. Further optimization of the combination with heat dissipation fins and PCM is also an important direction in the thermal management of LIB.

(3) The LIB capacity changes are related to the temperature. In the discharge rate cycles, the LIB temperature of PCM cooling and PCM combined with heat dissipation fins decreased slightly, and the capacity decreases compared with the natural convection condition. The battery temperature and capacity increase slightly under extreme conditions.

(4) The PCM have a bigger temperature impact on Sanyo LIB. Sanyo LIB generates more heat due to its large capacity, and PCM absorbs more latent heat. The temperature reduction effect of PCM on high rate discharge LIB is more obvious.

In the future study, PCM combined with other cooling way efficiently and developing the PCM of higher latent heat, better heat conduction performance will be an important direction of battery BTMS.

Author Contributions: Conceptualization, M.C., S.Z., and J.W. (Jingwen Weng); Methodology, M.C., D.O. and J.W. (Jian Wang); Investigation, L.Z., S.Z., and G.W.; Writing-Review \& Editing, M.C., S.Z., and X.W. All authors have read and agreed to the published version of the manuscript.

Funding: This research was funded by the National Key Research and Development Program of China (2018YFC0808600), the Open Project of State Key Laboratory of Fire Science (HZ2020-KF08), Natural Science Foundation of the Higher Education Institutions of Jiangsu Province (19KJB620003), and the Double Innovation Plan of Jiangsu province.

Conflicts of Interest: The authors declare no conflict of interest.

\section{Nomenclature}

$\begin{array}{ll}\text { Air } & \text { Air cooling } \\ \text { BTMS } & \text { Battery thermal management system } \\ \text { Excon } & \text { Extreme condition } \\ \text { LiFePO4 } & \text { Lithium iron phosphate } \\ \text { LIB } & \text { Lithium-ion battery } \\ \text { PCM } & \text { Phase change material } \\ \text { PCM-fin } & \text { PCM with heat dissipation fins } \\ \text { SOC } & \text { State of charge }\end{array}$

\section{References}

1. Li, X.; He, F.; Ma, L. Thermal management of cylindrical batteries investigated using wind tunnel testing and computational fluid dynamics simulation. J. Power Sources 2013, 238, 395-402. [CrossRef]

2. Weng, J.; Yang, X.; Ouyang, D.; Chen, M.; Zhang, G.; Wang, J. Comparative study on the transversal/lengthwise thermal failure propagation and heating position effect of lithium-ion batteries. Appl. Energy 2019, 255, 113761. [CrossRef]

3. Ouyang, D.; Weng, J.; Hu, J.; Liu, J.; Chen, M.; Huang, Q.; Wang, J. Effect of high temperature circumstance on lithium-ion battery and the application of phase change material. J. Electrochem. Soc. 2019, 166, A559-A567. [CrossRef]

4. Cicconi, P.; Landi, D.; Germani, M. Thermal analysis and simulation of Li-ion battery pack for a lightweight commercial EV. Appl. Energy 2017, 192, 159-177. [CrossRef]

5. Maleki, H.; Deng, G.; Anani, A.; Howard, J. Thermal stability studies of Li-ion cells and components. J. Electrochem. Soc. 1999, 146, 3224-3229. [CrossRef] 
6. Qian, Z.; Li, Y.; Rao, Z. Thermal performance of lithium-ion battery thermal management system by using mini-channel cooling. Energy Convers. Manag. 2016, 126, 622-631. [CrossRef]

7. Duan, X.; Naterer, G.F. Heat transfer in phase change materials for thermal management of electric vehicle battery modules. Int. J. Heat Mass Transf. 2010, 53, 5176-5182. [CrossRef]

8. Zou, D.; Liu, X.; He, R.; Zhu, S.; Bao, J.; Guo, J.; Hu, Z.; Wang, B. Preparation of a novel composite phase change material (PCM) and its locally enhanced heat transfer for power battery module. Energy Convers. Manag. 2019, 180, 1196-1202. [CrossRef]

9. Chen, M.; Bai, F.; Song, W.; Lv, J.; Lin, S.; Feng, Z.; Li, Y.; Ding, Y. A multilayer electro-thermal model of pouch battery during normal discharge and internal short circuit process. Appl. Therm. Eng. 2017, 120, 506-516. [CrossRef]

10. Wang, Z.; Zhang, H.; Xia, X. Experimental investigation on the thermal behavior of cylindrical battery with composite paraffin and fin structure. Int. J. Heat Mass Transf. 2017, 109, 958-970. [CrossRef]

11. Esmaeili, J.; Jannesari, H. Developing heat source term including heat generation atrest condition for Lithium-ion battery pack by up scaling information from cell scale. Energy Convers. Manag. 2017, 139, 194-205. [CrossRef]

12. Pesaran, A.A. Battery thermal models for hybrid vehicle simulations. J. Power Sources 2002, 110, 377-382. [CrossRef]

13. Giuliano, R.M.; Prasad, A.K.; Advani, S.G. Experimental study of an air-cooled thermal management system for high capacity lithium titanate batteries. J. Power Sources 2012, 216, 345-352. [CrossRef]

14. Chen, D.; Jiang, J.; Kim, G.-H.; Yang, C.; Pesaran, A. Comparison of different cooling methods for lithium ion battery cells. Appl. Therm. Eng. 2016, 94, 846-854. [CrossRef]

15. Zhang, Y.; Yu, X.; Feng, Q.; Zhang, R. Thermal performance study of integrated cold plate with power module. Appl. Therm. Eng. 2009, 29, 3568-3573. [CrossRef]

16. Zhang, G.Q.; Zhang, H.Y. Progress in application of phase change materials in battery module thermal management system. Mater. Rev. 2006, 20, 9-12. (In Chinese)

17. Liang, Z.; Zhongke, S. Application progress of phase change energy storage technology in automobile energy saving. J. Chem. Ind. Eng. 2018, 69, 17-25.

18. Du, K.; Calautit, J.; Wang, Z.; Wu, Y.; Liu, H. A review of the applications of phase change materials in cooling, heating and power generation in different temperature ranges. Appl. Energy 2018, 220, 242-273. [CrossRef]

19. Rao, Z:; Wang, S. a review of power battery thermal energy management. Renew Sustain. Energy Rev. 2011, 15, 4554-4571. [CrossRef]

20. Kandasamy, R.; Wang, X.Q.; Mujumdar, A.S. Application of phase change materials in thermal management of electronics. Appl. Therm. Eng. 2007, 27, 2822-2832. [CrossRef]

21. Nayak, K.C.; Saha, S.K.; Srinivasan, K.; Dutta, P. A numerical model for heat sinks with phase change materials and thermal conductivity enhancers. Int. J. Heat Mass Transfer 2006, 49, 1833-1844. [CrossRef]

22. Duan, X.; Naterer, G.F. Thermal protection of a ground layer with phase change materials. ASME J. Heat Transfer 2010, 132, 011301. [CrossRef]

23. Al-Hallaj, S.; Selman, J.R. A novel thermal management system for EV batteries using phase change material (PCM). J. Electrochem. Soc. 2000, 147, 3231-3236. [CrossRef]

24. Al-Hallaj, S.; Selman, J.R. Novel Thermal Management of Battery Systems. U.S. Patent 6,468,689 B1, 22 October 2002.

25. Mills, A.; Al-Hallaj, S. Simulation of passive thermal management system for lithium-ion battery packs. J. Power Sources 2005, 141, 307-315. [CrossRef]

26. Javani, N.; Dincer, I.; Naterer, G.F. Numerical modeling of sub module heat transfers with phase change material for thermal management of electric vehicle battery packs. J. Therm. Sc. Eng. Appl. 2015, 7, 031005. [CrossRef]

27. Weng, J.; Yang, X.; Zhang, G.; Ouyang, D.; Chen, M.; Wang, J. Optimization of the detailed factors in a phase-change-material module for battery thermal management. Int. J. Heat Mass Transf. 2019, 138, 126-134. [CrossRef]

28. Javani, N.; Dincer, I.; Naterer, G.F.; Yilbas, B.S. Heat transfer and thermal management with PCMs in a Li-ion battery cell for electric vehicles. Int. J. Heat Mass Transf. 2014, 72, 690-703. [CrossRef] 
29. Ling, Z.; Chen, J.; Fang, X. Experimental and numerical investigation of the application of phase change materials in a simulative power batteries thermal management system. Appl. Energy 2014, 21, 104-113. [CrossRef]

30. Wang, Z.; Zhang, Z.; Jia, L.; Yang, L. Paraffin and paraffin/aluminum foam composite phase change material heat storage experimental study based on thermal management of Li-ion battery. Appl. Therm. Eng. 2015, 78, 428-436. [CrossRef]

31. Li, W.Q.; Qu, Z.G.; He, Y.L.; Tao, Y.B. Experimental study of a passive thermal management system for high-powered lithium ion batteries using porous metal foam saturated with phase change materials. J. Power Sources 2014, 255, 9-15. [CrossRef]

32. Kizilel, R.; Sabbah, R.; Selman, J.R.; Al-Hallaj, S. an alternative cooling system to enhance the safety of Li-ion battery packs. J. Power Sources 2009, 194, 1105-1112. [CrossRef]

33. Zhao, J.; Lv, P.; Rao, Z. Experimental study on the thermal management performance of phase change material coupled with heat pipe for cylindrical power battery pack. Exp. Therm. Fluid Sci. 2017, 82, 182-188. [CrossRef]

34. Rao, Z.; Huo, Y.; Liu, X. Experimental investigation of battery thermal management system for electric vehicle based on paraffin/copper foam. J. Energy Inst. 2015, 88, 241-246. [CrossRef]

35. Alipanah, M.; Li, X. Numerical studies of lithium-ion battery thermal management systems using phase change materials and metal foams. Int. J. Heat Mass Transf. 2016, 102, 1159-1168. [CrossRef]

36. Hussain Tso, C.Y.; Chao, C.Y.H. Experimental investigation of a passive thermal management system for high-powered lithium ion batteries using nickel foam-paraffin composite. Energy 2016, 115, 209-218. [CrossRef]

37. Shang, S.; Jian-zu, Y.U.; Yong-qi, X.I.E.; Hong-xia, G.A.O.; ming, L. Temperature rise characteristics of phase change material/air cooling integrated thermal management system for lithium batteries. J. Beijing Univ. Aeronaut. Astronaut. 2017, 43, 1278-1286.

38. Azizi, S.M.Y.; Sadrameli, Y. Thermal management of a LiFePO4 battery pack at high temperature environment using a composite of phase change materials and aluminum wire mesh plates. Energy Convers. Manag. 2016, 128, 294-302. [CrossRef]

39. Sun, Z.; Fan, R.; Yan, F.; Zhou, T.; Zheng, N. Thermal management of the lithium-ion battery by the composite PCM-Fin structures. Int. J. Heat Mass Transf. 2019, 145, 118739. [CrossRef]

40. Zhang, Q.; White, R.E. Capacity fade analysis of a lithium ion cell. J. Power Sources 2008, 179, $793-798$.

Publisher's Note: MDPI stays neutral with regard to jurisdictional claims in published maps and institutional affiliations.

(C) 2020 by the authors. Licensee MDPI, Basel, Switzerland. This article is an open access article distributed under the terms and conditions of the Creative Commons Attribution (CC BY) license (http://creativecommons.org/licenses/by/4.0/). 